Original Research Paper

\title{
Performance Assessment of Solar Chimneys: Part I - Impact of Chimney Height on Power Output
}

\author{
${ }^{1,2}$ Erdem Cuce and ${ }^{3}$ Pinar Mert Cuce \\ ${ }^{1}$ Department of Mechanical Engineering, Faculty of Engineering, Recep Tayyip Erdogan University, \\ Zihni Derin Campus, 53100 Rize, Turkey \\ ${ }^{2}$ Low/Zero Carbon Energy Technologies Laboratory, \\ Faculty of Engineering, Recep Tayyip Erdogan University, Zihni Derin Campus, 53100 Rize, Turkey \\ ${ }^{3}$ Department of Energy Systems Engineering, Faculty of Engineering, Recep Tayyip Erdogan University, \\ Zihni Derin Campus, 53100 Rize, Turkey
}

\section{Article history}

Received: 14-06-2019

Revised: 19-06-2019

Accepted: 26-06-2019

Corresponding Author:

Erdem Cuce

Department of Mechanical Engineering, Faculty of Engineering, Recep Tayyip Erdogan University, Zihni Derin Campus, 53100 Rize, Turkey

Tel: +90 $4642237518-1152$

+904642237514

Email: erdem.cuce@erdogan.edu.tr

\begin{abstract}
Solar chimney is a truly sustainable and green energy technology, which is a potential alternative to carbon-based energy economy. The working principle of solar chimneys is based on the buoyant nature of air to turn a turbine that produces electrical power. Solar chimneys are highly in the centre of interest among all solar energy applications since they enable both day and night time operation owing to greenhouse and chimney effects. A typical solar chimney consists of three main parts as chimney, collector and turbine. When the in-situ applications of solar chimneys are gone through, it can be easily asserted that the driving force in electricity generation comes from the chimney effect as a consequence of the notable pressure differences between the inlet and outlet of the chimneys. In most cases, the greenhouse effects on power output are considered auxiliary only due to non-optimised geometric properties for the air medium beneath the collector. Within the scope of this CFD research, the impacts of chimney height on power output of a typical solar chimney are evaluated. A commercial and reliable CFD software ANSYS FLUENT is considered for the numerical analyses. For different chimney heights, the average velocity at the inlet of chimney in which the turbine is placed is determined by applying k- $\varepsilon$ turbulence model, continuity, momentum and energy equations for a $2 \mathrm{D}$ model. The results reveal that there is an exponential relationship between the pressure difference and the average air velocity and the solar chimney is found to be practical after a certain value of chimney height. For a chimney and collector diameter of 10 and $1000 \mathrm{~m}$, respectively, the average velocity at the inlet of chimney is calculated to be $25.17 \mathrm{~m} / \mathrm{s}$ for a chimney height of $100 \mathrm{~m}$, whereas it is $18.06 \mathrm{~m} / \mathrm{s}$ for the height of $50 \mathrm{~m}$. The findings are of vital importance in terms of feasibility studies on solar chimneys since they give a clear understanding about the influence of chimney height on the electrical power output of any solar chimney power plant.
\end{abstract}

Keywords: Solar Chimney, Chimney Height, Pressure Difference, Average Velocity, Power Output

\section{Introduction}

Solar energy is ascribed to have the greatest potential among the other renewable energy technologies to be able to mitigate the dominant impact of fossil fuel based energy economy at global scale (Cuce et al., 2018). There is a wide range of solar energy applications from solar thermal to solar electricity as well as concentrating cogeneration and trigeneration technologies (Daneshazarian et al., 2017). Solar electricity is currently dominated by Photovoltaics (PVs) worldwide owing to the remarkable advancements in semiconductor materials and notable enhancements in PV module efficiencies (Cuce et al., 2019). However, overall system performance and payback period of PVs are highly dependent on the environmental and operational parameters and for the 
regions with moderate solar radiation potential, PV systems are not reported to be feasible in most cases. Therefore, alternative technologies are taken into consideration like solar chimneys which can be operated at a steady efficiency range irrespective of climatic conditions (Schlaich, 1996).

A solar chimney, which is illustrated in Fig. 1, typically consists of three main parts as collector, chimney and turbine. The core of the structure is the chimney which is basically a huge pressure tower. Depending on the height, a massive pressure difference takes place between the inlet and the outlet of the chimney, which enables electricity generation in summer and winter as being independent of climatic conditions. The chimneys are usually constructed by thermally insulative materials and thus adiabatic conditions are usually considered at the boundaries of chimneys in numerical modelling (Toghraie et al., 2018). Collectors are made of transparent materials such as glass or polythene to maximize the solar radiation penetration into the air medium. As a consequence of the greenhouse effect, air with high thermal energy content accelerates toward the centre of collector and generates electricity by turning the turbine which is located at the inlet of chimney (Fasel et al., 2013). Thermal energy storage can also be considered on the ground of collector area to improve the night time performance of solar chimney power plants (Amudam and Chandramohan, 2019).

There is a common view about solar chimney power plants that a gigantic chimney is required for maximum power output (Zhou et al., 2009), however, it is not economically viable to construct power plants with different heights in order to evaluate the chimney effect. Chimney height plays a key role in pressure difference between the inlet and the outlet of the chimney, hence geometric optimisation of chimney is of vital importance for improved power output. On the other hand, there are some shortcomings of solar chimney power plants with excessive chimney height. For instance, the buoyancy impacts weaken and flow losses rise with increasing chimney height (Guo et al., 2019). In addition, it is reported in theoretical analyses that the chimney height is considerably affected by the collector radius. Chimney height, in most cases, is evaluated along with the chimney diameter through the term slenderness. The slenderness is expressed as the ratio of chimney height to the chimney diameter. The optimum value of slenderness is reported to be 12 to be able to overcome the strong wind effects, which are indispensable to take place around the top of the chimney (Kashiwa and Kashiwa, 2008). On the other hand, there is a risk of cold air inflow to the solar chimney power plant for the lower slenderness values (Pretorius, 2007). In another research, it is reported that ambient cross wind effects increase with the chimney height, which have positive influence on the power output of the plant (Ming et al., 2017). In most of the works, the ratio of chimney diameter to chimney height is addressed to be 0.1 for maximum air velocity at the chimney inlet (Kasaeian et al., 2017), however, the said works are mostly based on numerical models and further experimental justifications are required.

The efficiency of solar chimney power plants is reported to be solely dependent on the chimney height since the dominant mechanism in the energy conversion process is the pressure difference between the chimney inlet and outlet (Lal et al., 2016). In this respect, different models are proposed to estimate the chimney efficiency as a function of chimney height as carried out by Dai et al. (2003). The said models are observed to give successful predictions in most cases. However, it needs to be noted that the chimney efficiency and the power output of the plant do not merely depend on chimney height and other geometric properties are of significant relevance. Within the scope of this CFD research, a 2D model is constructed to analyse the impacts of chimney height on the average velocity of air at the chimney inlet in which the turbine is fixed. The chimney height is correlated with the pressure difference across the chimney and the velocity distribution of air at the inlet section of the chimney is achieved for different values of pressure difference. The numerical research is conducted for different number of cells and mesh independent solution is obtained for each case. The analyses are performed for a constant solar intensity of $200 \mathrm{~W} / \mathrm{m}^{2}$. Adiabatic conditions are assumed to take place on the chimney boundaries. The rest of the geometrical properties is considered according to the pilot projects in literature.

\section{Solar Chimney Power Plant}

The structural details of solar chimney power plant are given in Table 1. Chimney diameter and chimney height are selected to be 10 and $100 \mathrm{~m}$, respectively which corresponds to a slenderness value of 10 . Collector radius is taken to be $500 \mathrm{~m}$, which is in good agreement with the pilot models in literature. The height of air vents at the inlet of collector is $1 \mathrm{~m}$ and it reaches $4 \mathrm{~m}$ at the inlet of the chimney. The slope of the said configuration is in good accordance with the previous works. Adiabatic boundary condition is considered on the external surface of chimney. Collectors are subjected to constant heat flux of $200 \mathrm{~W} / \mathrm{m}^{2}$. At the inlet of air vents, pressure inlet condition is selected in the CFD analyses whereas pressure outlet is considered at the chimney outlet by taking the actual pressure drop by chimney height into consideration.

Table 1: Structural details of solar chimney power plant

\begin{tabular}{ll}
\hline Chimney diameter & $10 \mathrm{~m}$ \\
Chimney height & $100 \mathrm{~m}$ \\
Slenderness value & 10 \\
Collector radius & $500 \mathrm{~m}$ \\
Air vent height at collector inlet & $1 \mathrm{~m}$ \\
Air vent height at collector centre & $4 \mathrm{~m}$ \\
\hline
\end{tabular}




\section{CFD Analyses of Solar Chimney Power Plant}

Solar chimney power plant with the abovementioned structural and operational parameters is numerically analysed via a well-known and reliable commercial software ANSYS FLUENT. For various chimney heights, the average velocity at the inlet of chimney in which the turbine is mounted is achieved by applying $\mathrm{k}-\varepsilon$ turbulence model, continuity, momentum and energy equations for a 2D model. Air beneath the solar collectors is selected as ideal gas in the analyses and natural convection in the said medium is modelled. PRESTO approach is preferred in the research for a precise modelling of heat transfer in the air medium which is based on pressure-based solver. Quadratic mesh is considered in the analyses with convergence criteria of 10-6 for continuity, momentum and energy equations. Under-relaxation factors are successfully controlled in the iteration process in order to obtain the identical convergence tendency. Thermal conductivity, density and specific heat capacity of ambient air outside the chimney are taken to be $0.0242 \mathrm{~W} / \mathrm{mK}, 1.225 \mathrm{~kg} / \mathrm{m}^{3}$ and $1006.43 \mathrm{~J} / \mathrm{kgK}$, respectively.

\section{Results and Discussion}

The CFD analysis of solar chimney power plant is carried out for a chimney diameter of $10 \mathrm{~m}$ and for a slenderness value of 10 , which corresponds to a chimney height of $100 \mathrm{~m}$. At this height, the theoretical pressure difference between the inlet and the outlet of chimney is calculated to be $1196 \mathrm{~Pa}$. By assuming the said pressure difference to be about $1200 \mathrm{~Pa}$ at a chimney height of $100 \mathrm{~m}$, the pressure difference is varied from 1200 to $100 \mathrm{~Pa}$, which corresponds to the different chimney heights or different slenderness values. By doing so, the average velocity at the chimney inlet is numerically determined and the impacts of chimney height on the performance of solar chimney power plant are evaluated. As shown in Fig. 2, for a pressure difference of $100 \mathrm{~Pa}$, the average velocity at the chimney inlet is determined to be $7.19 \mathrm{~m} / \mathrm{s}$. As depicted in Fig. 3, for a pressure difference of $200 \mathrm{~Pa}$, the average velocity at the chimney inlet is found to be $10.27 \mathrm{~m} / \mathrm{s}$. As illustrated in Fig 4, for a pressure difference of $300 \mathrm{~Pa}$, the average velocity at the chimney inlet is specified to be $12.66 \mathrm{~m} / \mathrm{s}$. The average velocity is determined to be $14.66 \mathrm{~m} / \mathrm{s}$ for a pressure difference of $400 \mathrm{~Pa}$ as given in Fig. 5. It is noted from the tendency that the average velocity at the chimney inlet notably increases with the chimney height. As shown in Fig. 6, for a pressure difference of $500 \mathrm{~Pa}$, the average velocity at the chimney inlet is found to be $16.45 \mathrm{~m} / \mathrm{s}$. Through the similar manner, the pressure difference is varied up to $1200 \mathrm{~Pa}$ and the average velocities are specified. For a pressure difference of 600 , $700,800,900,1000,1100$ and $1200 \mathrm{~Pa}$, the average velocity of air is determined to be 18.06, 19.59, 20.45, $22.25,23.48,24.66$ and $25.17 \mathrm{~m} / \mathrm{s}$ respectively as illustrated in Fig. 7-13. Through the detailed CFD analyses, it is understood that there is an exponential relationship between the pressure difference and average velocity figures. This is better clarified in Fig. 14.

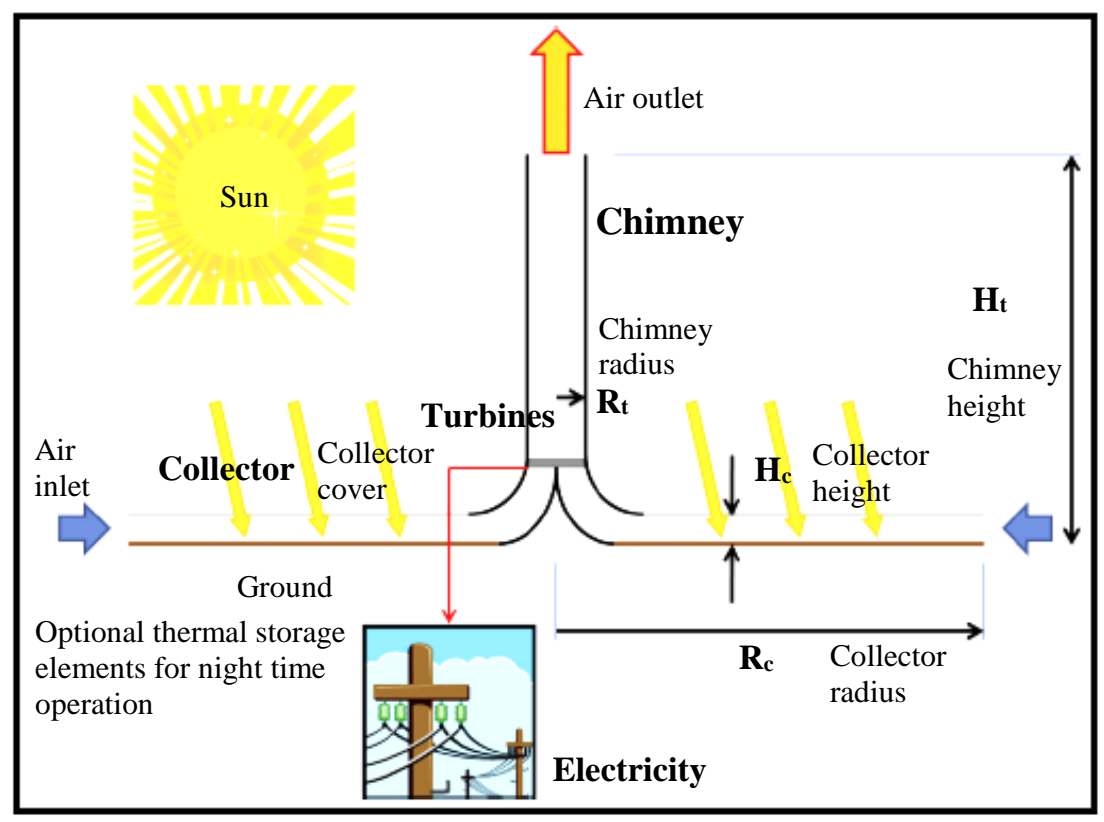

Fig. 1: Schematic of a typical solar chimney power plant (Toghraie et al., 2018) 


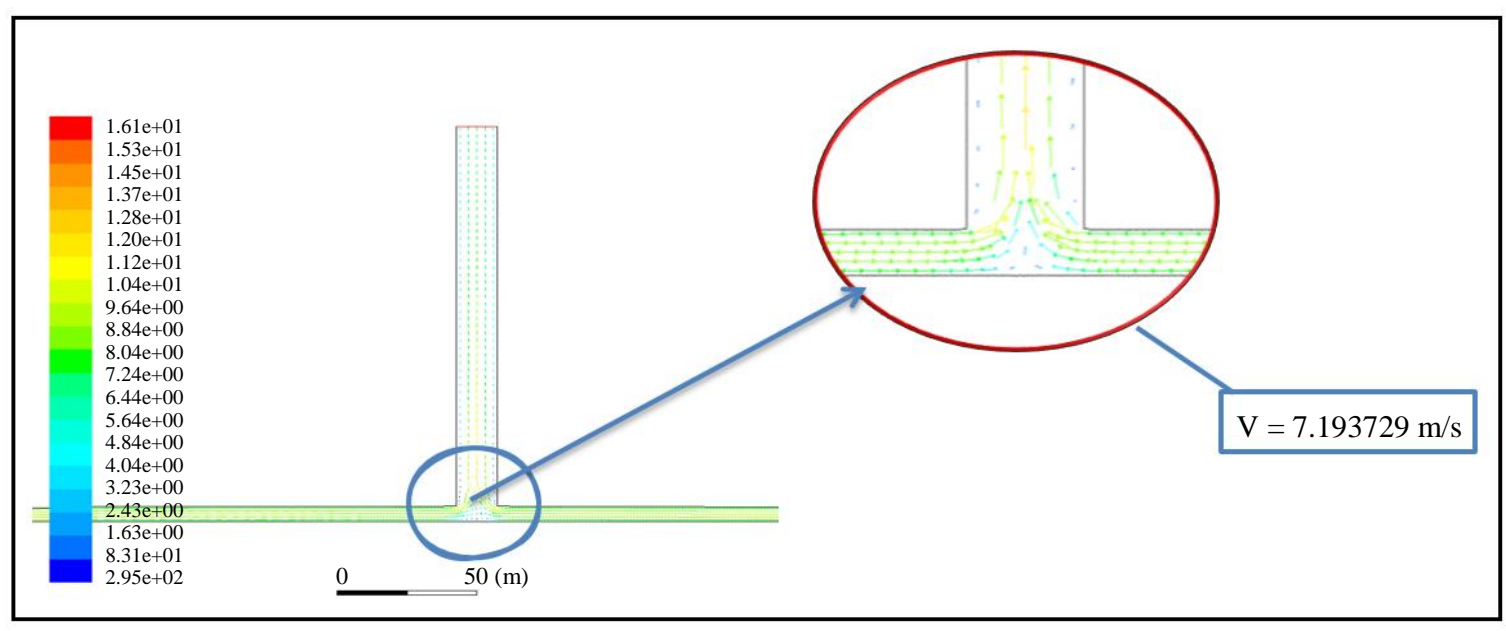

Fig. 2: Average velocity of air at the inlet of solar chimney for a pressure difference of $100 \mathrm{~Pa}$

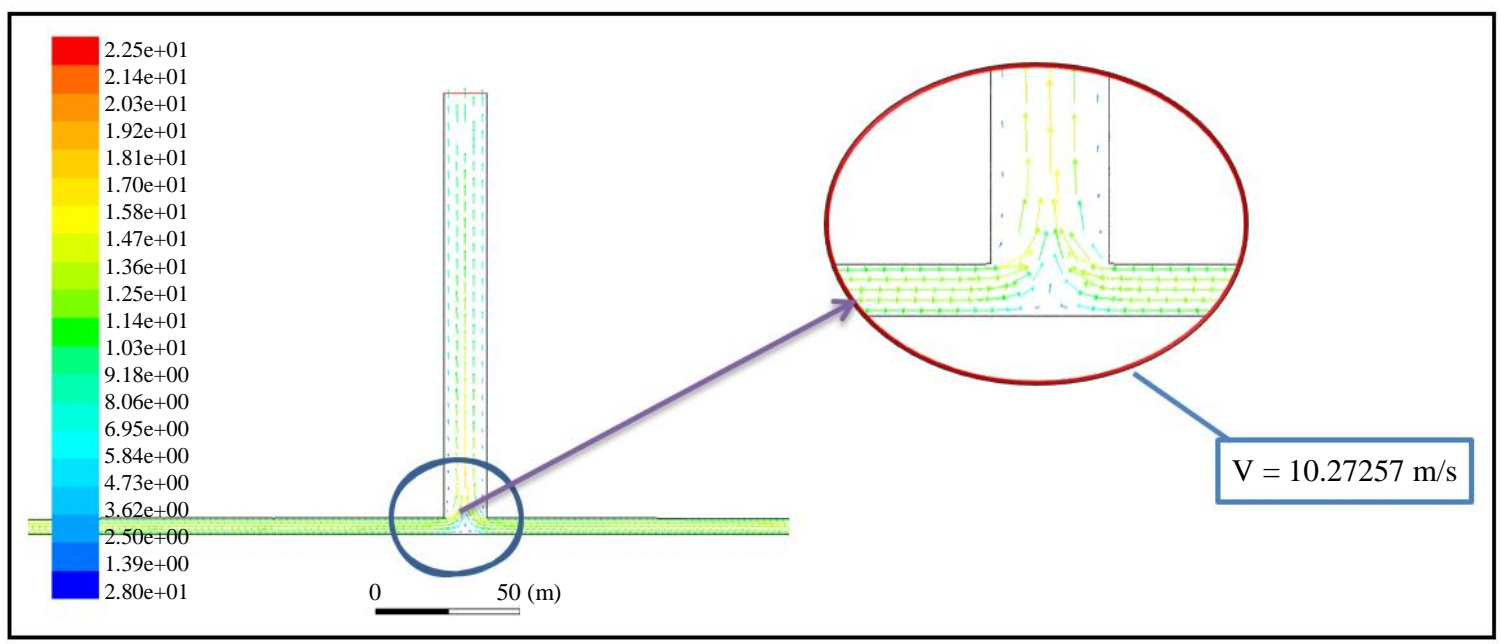

Fig. 3: Average velocity of air at the inlet of solar chimney for a pressure difference of $200 \mathrm{~Pa}$

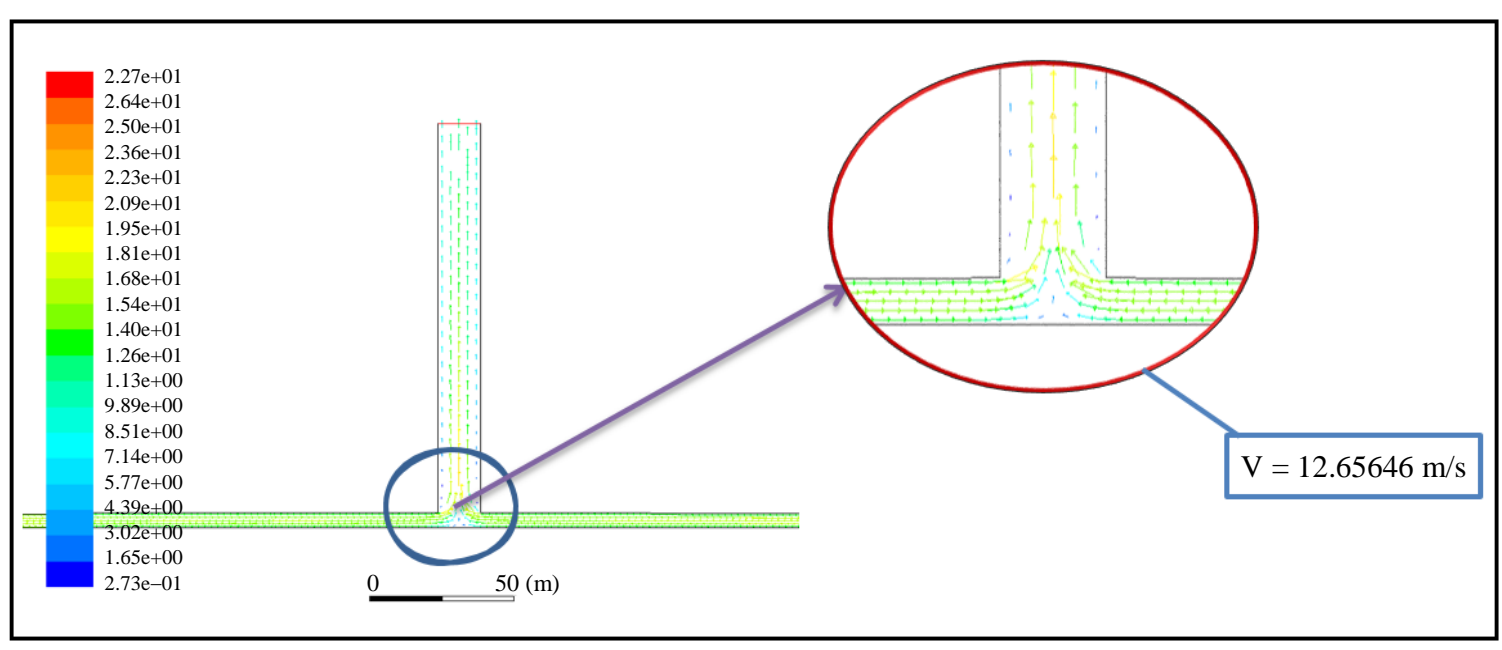

Fig. 4: Average velocity of air at the inlet of solar chimney for a pressure difference of $300 \mathrm{~Pa}$ 

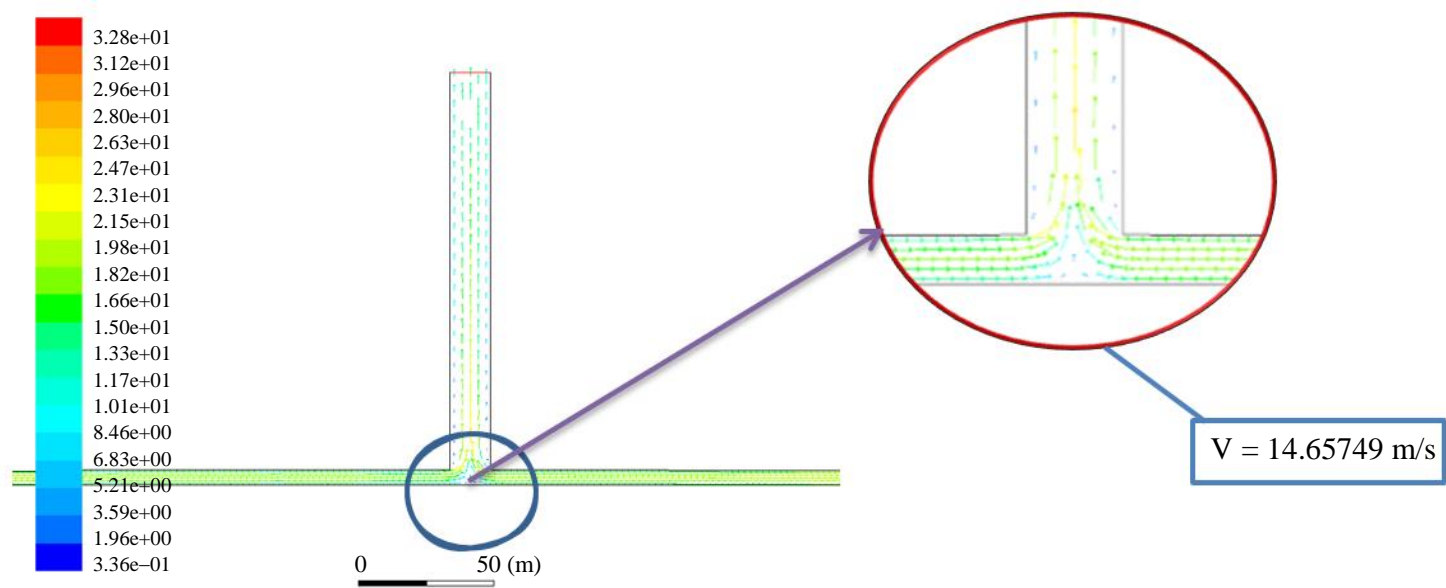

Fig. 5: Average velocity of air at the inlet of solar chimney for a pressure difference of $400 \mathrm{~Pa}$

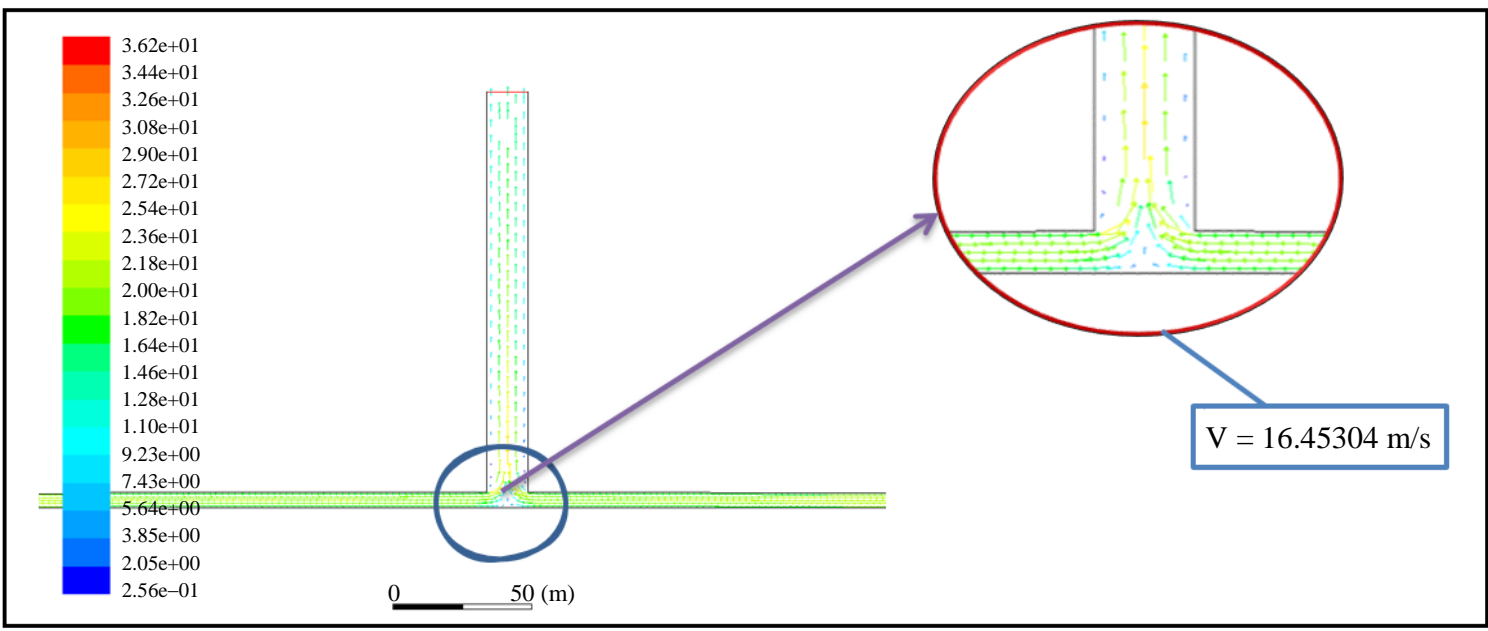

Fig. 6: Average velocity of air at the inlet of solar chimney for a pressure difference of $500 \mathrm{~Pa}$

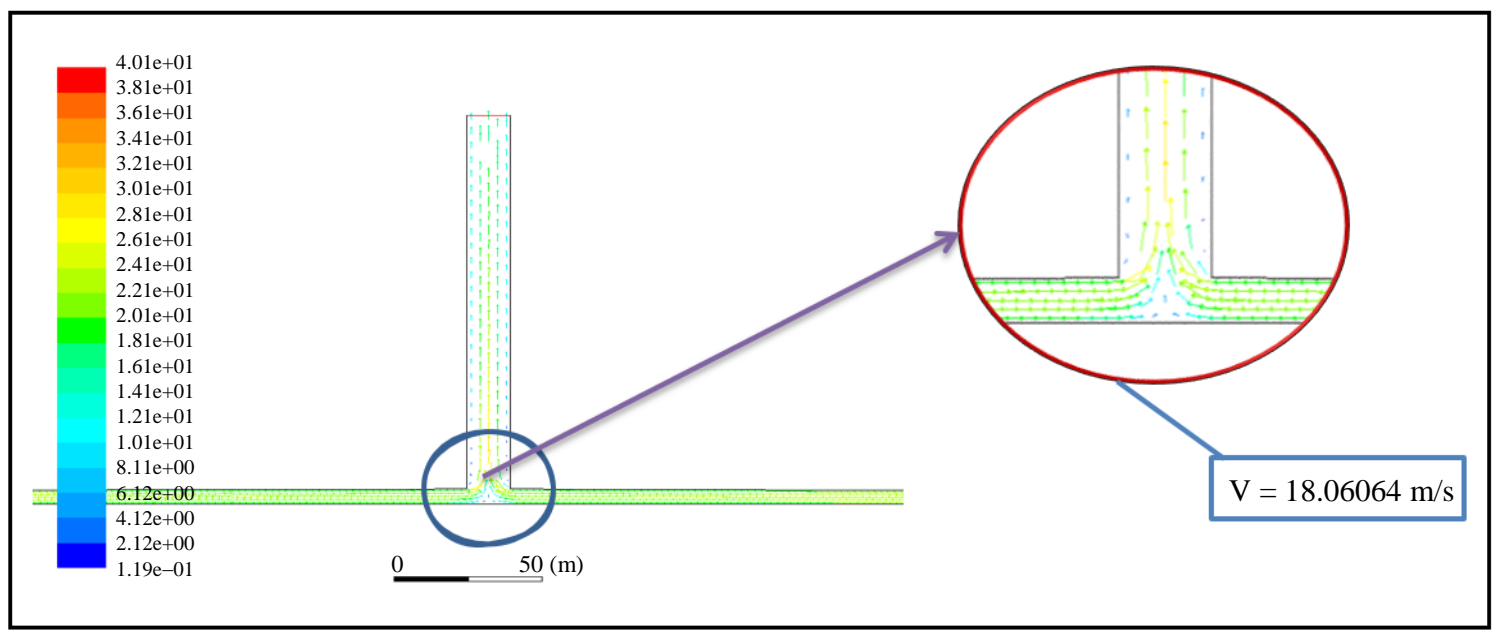

Fig. 7: Average velocity of air at the inlet of solar chimney for a pressure difference of $600 \mathrm{~Pa}$ 


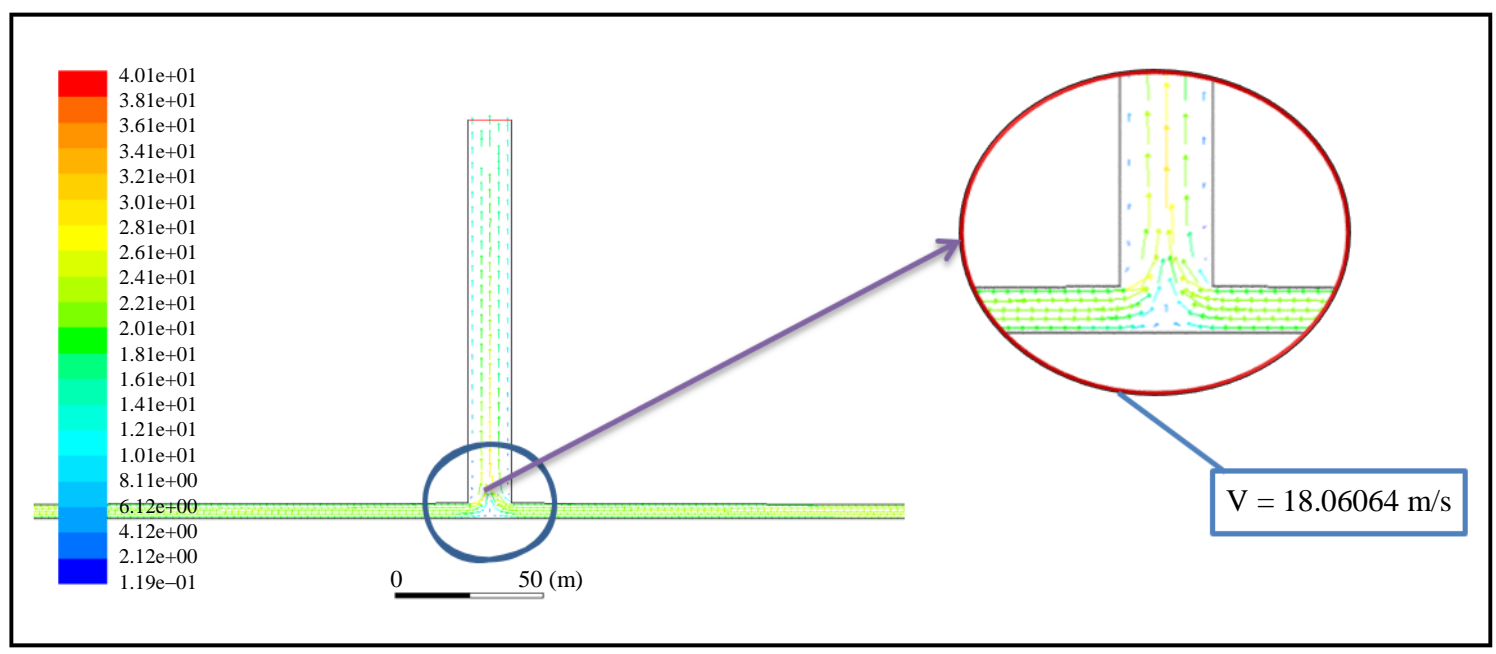

Fig. 8: Average velocity of air at the inlet of solar chimney for a pressure difference of $700 \mathrm{~Pa}$

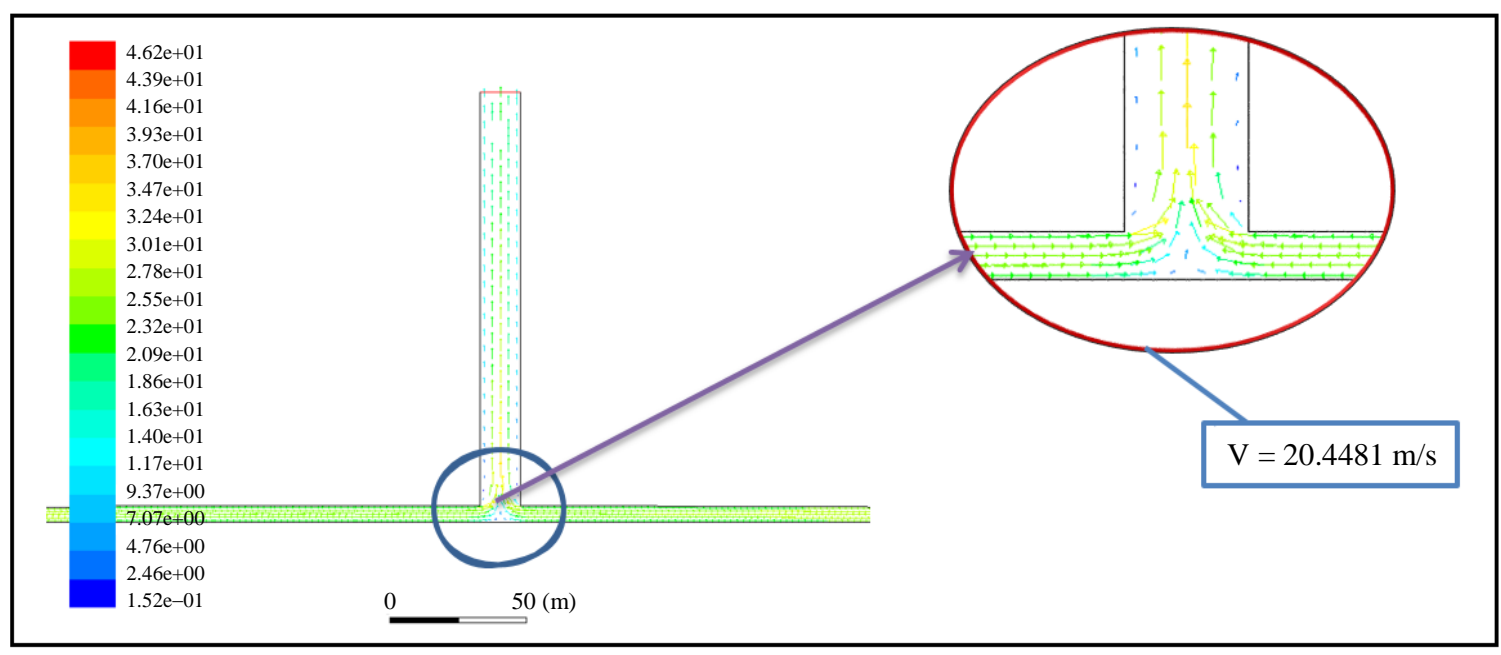

Fig. 9: Average velocity of air at the inlet of solar chimney for a pressure difference of $800 \mathrm{~Pa}$

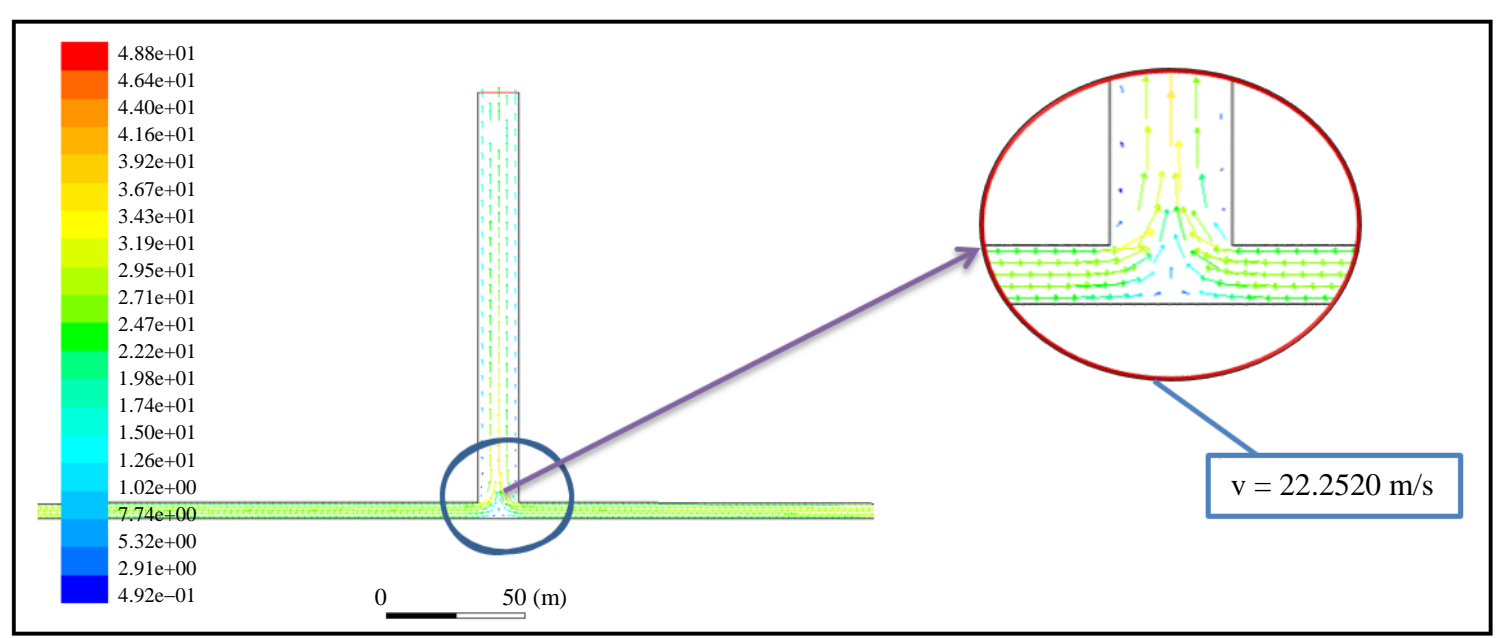

Fig. 10: Average velocity of air at the inlet of solar chimney for a pressure difference of $900 \mathrm{~Pa}$ 


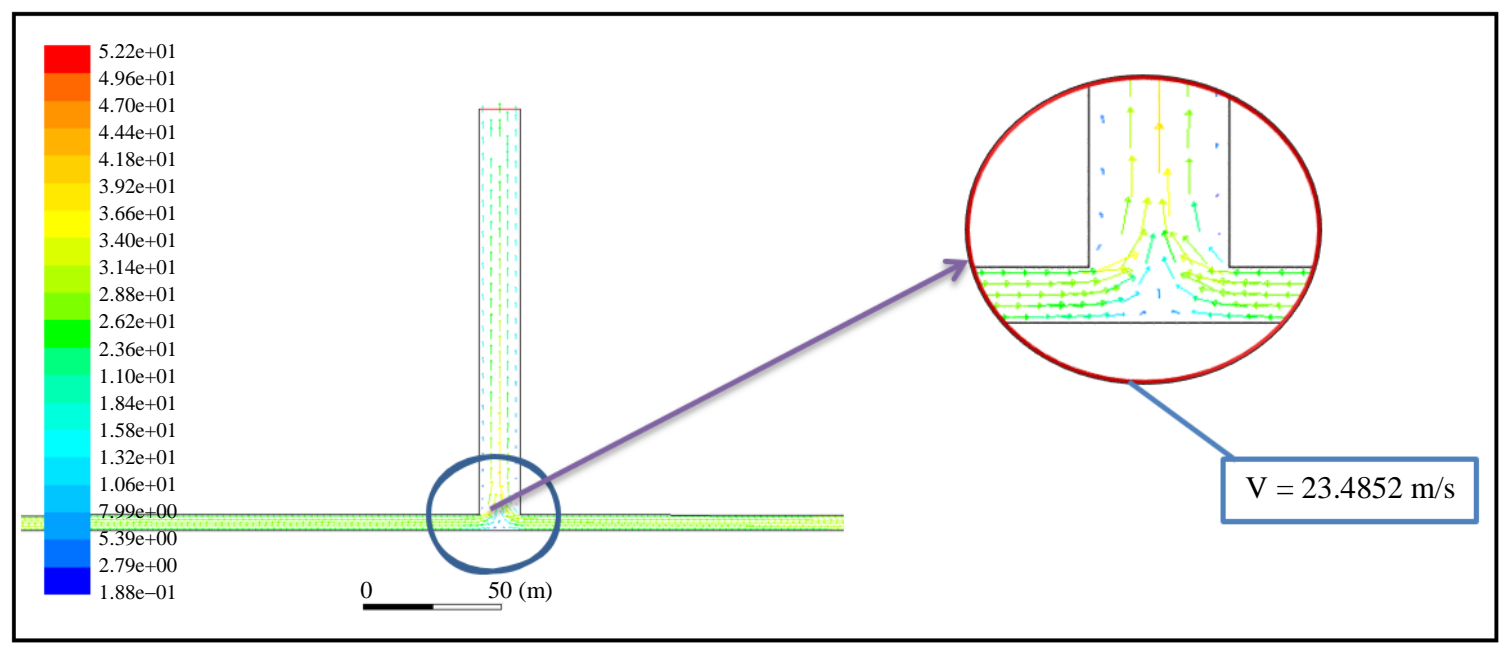

Fig. 11: Average velocity of air at the inlet of solar chimney for a pressure difference of $1000 \mathrm{~Pa}$

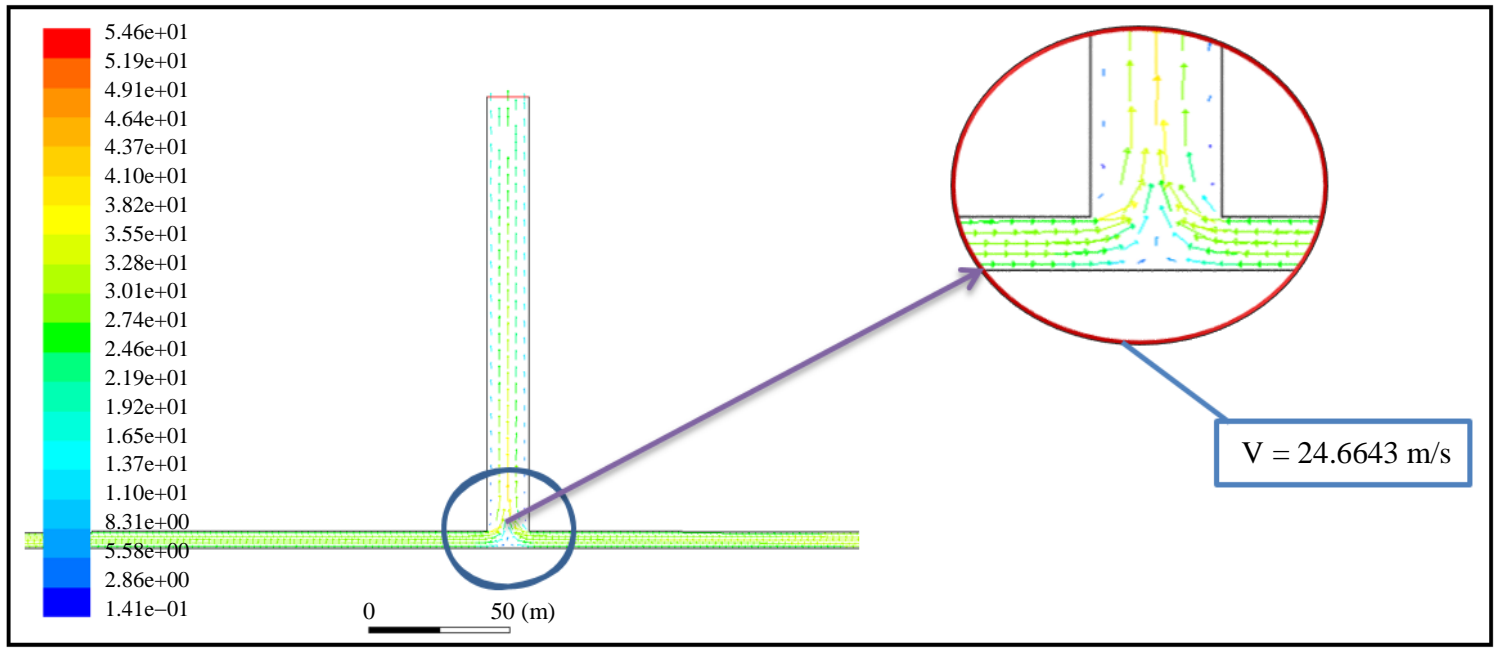

Fig. 12: Average velocity of air at the inlet of solar chimney for a pressure difference of $1100 \mathrm{~Pa}$

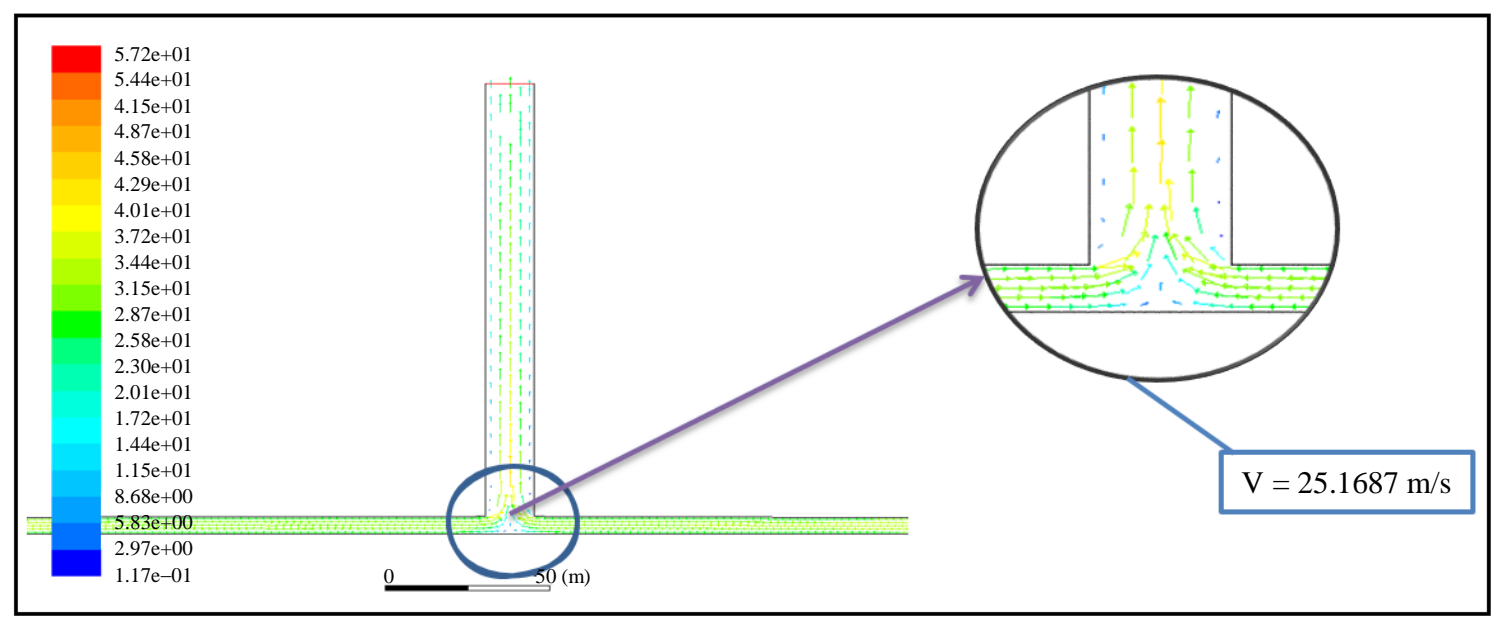

Fig. 13: Average velocity of air at the inlet of solar chimney for a pressure difference of $1200 \mathrm{~Pa}$ 


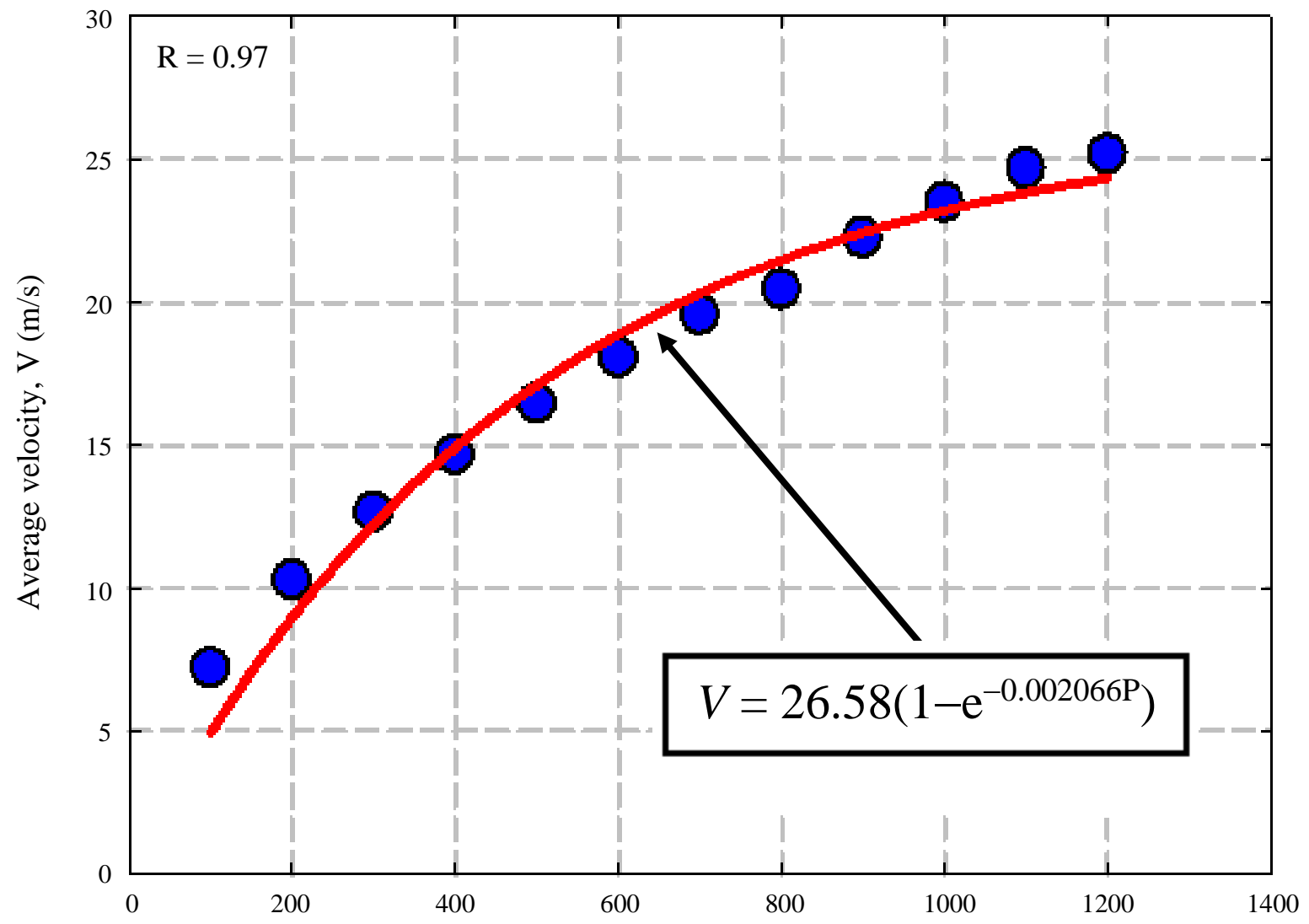

Pressure difference, $\mathrm{P}(\mathrm{Pa})$

Fig. 14: Average velocity of air vs. pressure difference between the inlet and the outlet of chimney for chimney heights up to $100 \mathrm{~m}$ and for a solar intensity of $200 \mathrm{~W} / \mathrm{m}^{2}$

A regression analysis is also carried out to achieve a correlation between velocity and pressure difference values. Correlation coefficient is calculated to be 0.97 , which is acceptable and promising for such a research. The velocity contours are in good accordance with each other which justifies the reliability of the research. In practice, most of the pilot projects on solar chimney power plants have a chimney height up to $100 \mathrm{~m}$. In this respect, the correlation developed within the scope of this CFD research is of vital importance for the feasibility studies on solar chimneys. Life-cycle cost analyses of solar chimneys are conducted according to the average velocity of air at the chimney inlets. From this point of view, the results are useful for the power output predictions of solar chimney power plants.

\section{Conclusion}

The impacts of chimney height on the average velocity of air at the chimney inlet are numerically analysed. For various chimney heights thus for different slenderness values, the average velocity figures are achieved through a CFD methodology. The results reveal that there is an exponential relationship between the pressure difference and velocity figures. For a chimney height of $100 \mathrm{~m}$, the average velocity is calculated to be $25.17 \mathrm{~m} / \mathrm{s}$ whereas it is $18.06 \mathrm{~m} / \mathrm{s}$ for the chimney height of $50 \mathrm{~m}$. The greater values of chimney height correspond to greater power outputs as expected. However, the slenderness value increases with the chimney height as well and this is a handicap since the wind effects are inevitable and dominant at greater values of chimney height.

\section{Author's Contributions}

Erdem Cuce: Mentoring the research, revising/editing the body.

Pinar Mert Cuce: Preparation of the main draft following the collecting data and evaluating the findings.

\section{Ethics}

This article is original and contains unpublished material. The corresponding author confirms that all of the other authors have read and approved the manuscript and no ethical issues involved. 


\section{References}

Amudam, Y. and V.P. Chandramohan, 2019. Influence of thermal energy storage system on flow and performance parameters of solar updraft tower power plant: A three dimensional numerical analysis. J. Cleaner Production, 207: 136-152.

Cuce, E., E.K. Oztekin and P.M. Cuce, 2018. Hybrid Photovoltaic/Thermal (HPV/T) systems: From theory to applications. Energy Res. J., 9: 1-71.

Cuce, E., P.M. Cuce and T. Bali, 2019. Impact of humidity on current parameters of solar cells. J. Energy Syst., 2: 84-96.

Dai, Y.J., H.B. Huang and R.Z. Wang, 2003. Case study of solar chimney power plants in Northwestern regions of China. Renewable Energy, 28: 1295-1304.

Daneshazarian, R., E. Cuce and P.M. Cuce, 2017. An overview of Concentrating Photovoltaic Thermal (CPVT) collectors. Energy Res. J., 8: 11-21.

Fasel, H.F., F. Meng, E. Shams and A. Gross, 2013. CFD analysis for solar chimney power plants. Solar Energy, 98: 12-22.

Guo, P., T. Li, B. Xu, X. Xu and J. Li, 2019. Questions and current understanding about solar chimney power plant: A review. Energy Conversion Management, 182: 21-33.

Kasaeian, A.B., S. Molana, K. Rahmani and D. Wen, 2017. A review on solar chimney systems. Renewable Sustainable Energy Rev., 67: 954-987.
Kashiwa, B.A. and C.B. Kashiwa, 2008. The solar cyclone: A solar chimney for harvesting atmospheric water. Solar Energy, 33: 331-339.

Lal, S., S.C. Kaushik and R. Hans, 2016. Experimental investigation and CFD simulation studies of a laboratory scale solar chimney for power generation. Sustainable Energy Technologies Assessments, 13: 13-22.

Ming, T., Y. Wu, R.K. Richter, W. Liu and S.A. Sherif, 2017. Solar updraft power plant system: A brief review and a case study on a new system with radial partition walls in its collector. Renewable Sustainable Energy Rev., 69: 472-487.

Pretorius, J.P., 2007. Optimization and control of a large-scale solar chimney power plant. Ph.D. Thesis, University of Stellenbosch.

Schlaich, J., 1996. The solar chimney: electricity from the sun. Edition Axel Menges.

Toghraie, D., A. Karami, M. Afrand and A. Karimipour, 2018. Effects of geometric parameters on the performance of solar chimney power plants. Energy, 162: 1052-1061.

Zhou, X., J. Yang, B. Xiao, G. Hou and F. Xing, 2009. Analysis of chimney height for solar chimney power plant. Applied Thermal Eng., 29: 178-185. 